\title{
Elevated Free Thyroxine Levels Detected by a Neonatal Screening System
}

\author{
TOSHIHIRO TAJIMA, WAKAKO JO, KAORI FUJIKURA, MASARU FUKUSHI, AND KENJI FUJIEDA
}

\begin{abstract}
Department of Pediatrics [T.T., W.J.], Hokkaido University School of Medicine, Sapporo, Hokkaido 060-8635, Japan; Sapporo City Institute of Public Health [K.F., M.F.], Sapporo, Hokkaido 003-8505, Japan; Department of Pediatrics [K.F.], Asahikawa Medical College School of Medicine, Asahikawa, Hokkaido 078-8510, Japan
\end{abstract}

\begin{abstract}
In Sapporo city of Japan, neonatal screening for congenital hypothyroidism has used the measurement of free thyroxine (T4) and thyroid-stimulating hormone (TSH) in the filter-paper blood spot. This system has enabled us to identify hyperthyroxinemic diseases. Filter papers were collected from neonatal infants born at $4-6 \mathrm{~d}$ of age and neonates who showed elevated free T4 $(>4.0$ ng/dL, 4 SD above the mean) were studied. Between January 2000 and December 2006, 83,232 newborns were screened. Eleven infants demonstrated persistent hyperthyroxinemia. One patient with slightly elevated free T4 and normal TSH was diagnosed as having familial dysalbuminemic hyperthyroxinemia (FDH). The other two patients with elevated free T4 without suppressed TSH were considered as having resistance of thyroid hormone (RTH), and analysis of thyroid hormone receptor (TR) $\beta$ gene confirmed the diagnosis. The remaining eight patients were diagnosed as having neonatal Graves' disease (NGD). Seven of eight pregnant women were treated with antithyroid drug and thus only one unrecognized NGD during pregnancy was detected by screening. Our screening system enables for early awareness of RTH and FDH. Regarding Graves' disease, the benefit of elevated free T4 screening is small, because most pregnant women with Graves' disease were managed. (Pediatr Res 66: 312-316, 2009)
\end{abstract}

$\mathrm{C}$ ongenital hypothyroidism is the most prevalent endocrine disorder in the newborn, with a rather constant worldwide incidence of permanent congenital hypothyroidism of 1:3000 to $1: 4000$ newborns $(1,2)$. The main purpose of neonatal mass screening for congenital hypothyroidism is early detection and treatment to hypothyroidism. During the past three decades, this screening has been very successful with the vast majority of patients with congenital hypothyroidism achieving normal neurologic outcome (1-3). Two methods for the screening system are now used. Most screening programs in Europe and Asia, including Japan, use primary thyroidstimulating hormone (TSH) screening. Another program is thyroxine (T4) or free T4-based neonatal screening (4-6). T4 or free $\mathrm{T} 4$ screening enables the detection of hyperthyroxinemia in addition to congenital hypothyroidism. In hyperthyroxinemic disorders, neonatal Graves' disease (NGD) is thought to be the most prevalent and the occurrence is estimated as one in 10,000 to 50,000 newborn infants (7-9). Activating mutation of TSH receptor mutations and gain of function mutations

Received February 9, 2009; accepted April 29, 2009.

Correspondence: Toshihiro Tajima, MD, PhD, Department of Pediatrics, Hokkaido University School of Medicine, N15, W7, Sapporo, Japan; e-mail: tajeari@med.hokudai.ac.jp of Gs $\alpha$ protein McCnune-Albright syndrome has been also reported to cause hyperthyroidism in neonatal period $(10,11)$.

LaFranchi et al. (12) have reported the first systematic study to screen neonatal hyperthyroxinemia using T4 screening in Oregon. According to their study, any case with NGD among 80,884 infants was not detected. Instead, 10 had thyroxinebinding globulin excess, five were thought to be familial dysalbuminemic hyperthyroxinemia (FDH), and two had resistance of thyroid hormone (RTH). After this report, the study of differential diagnosis of neonatal hyperthyroxinemia detected by neonatal screening is scarce $(12,13)$.

In Sapporo of Japan, neonatal screening for congenital hypothyroidism has been based on simultaneous TSH and free T4 measurements and was effective for the identification of primary and central congenital hypothyroidism (6). As free T4 measurement could also identify hyperthyroxinemic disorder, we have determined the type of diseases detected by elevated free T4 in neonatal screening between 2000 and 2006 in Sapporo of Japan.

\section{METHODS}

A neonatal screening for congenital hypothyroidism and thyroid hormone measurement. In Sapporo of Japan, $\sim 10,000$ infants were born annually. Almost $100 \%$ of these newborns were subjected to neonatal screening. The neonatal screening program for congenital hypothyroidism was based on simultaneous TSH and free T4 measurements in dried blood on filter paper specimens. Dried blood samples on filter paper were collected from neonatal infants born in Sapporo City at 4-6 d of age from maternity and parturition clinics to screening center. Whole blood was drawn by heel prick, and TSH and free T4 were then measured from one punched 3.2- $\mathrm{mm}$ circle, which corresponded to $3.5 \mu \mathrm{L}$ of whole blood. TSH and free T4 were measured by ELISA kits (Bayer Medical Enzaplate Neo-TSH and Enzplate N-FT4 kits, Japan). In free T4 measurement, intraassay coefficient variation was $7.6-8.1 \%$ and interassay coefficient variation was $9.4-18 \%$. To detect infants who were at risk for hyperthyroxinemic disorders, we determined the upper cutoff values for free T4 as $4.0 \mathrm{ng} / \mathrm{dL}$. This cutoff value represented $>4$ $\mathrm{SD}$ above the mean. If infants had free $\mathrm{T} 4$ values $>4.0 \mathrm{ng} / \mathrm{dL}$, then second heel puncture was requested.

In one family of FDH, serum T4, triiodothyronine (T3), free $\mathrm{T} 4$, free $\mathrm{T} 3$, and TSH were measured using commercial RIA kits (Dinabot, Matsudo, Japan). Serum free T4 and free T3 were also measured by one-step labeled antibody radioassay (Amerlex MAB free T4 and free T3 kits, Trinity Biotech, Ireland).

Gene analysis. DNA analysis of thyroid diseases was approved by the ethical committee of Hokkaido University School of Medicine, and informed consent for DNA analysis was obtained from their parents. To examine the

\footnotetext{
Abbreviations: FDH, Familial dysalbuminemic hyperthyroxinemia; RTH, Resistance of thyroid hormone; TR $\boldsymbol{\beta}$, Thyroid hormone receptor; TSH, Thyroid stimulating hormone; T4, Thyroxine; T3, Triiodothyronine
} 
mutation (R218P) in exon 7 of the albumin gene, the endonuclease digestion/ allele-specific primer method was used as described previously (14). For the thyroid hormone receptor (TR) $\beta$ gene analysis, each exon was amplified by PCR according to a previous report (15) and directly sequenced.

\section{RESULTS}

From January 2000 to December 2006, a total of 83,232 infants were screened. During this period, 28 infants demonstrated elevated free T4 at first screening. Of 28 infants, 11 infants showed persistent increased free $\mathrm{T} 4$, whereas the second screening sample of 17 infants decreased to normal levels. Values of the first screening in the 11 infants with persistent hyperthyroxinemia who were subjected to further evaluation were shown in Table 1.

Cases of NGD. Of these 11 infants, eight infants were diagnosed as having NGD. Therefore, the estimated incidence of NGD is one in 10,404 during this period. Thyroid function of these patients was summarized in Table 2 . Because our city had several central hospitals for maternal and neonatal care, mothers of patient 2, 4, 5, and 6 were referred to our city for further follow-up and treatment for maternal Graves' disease from other district. Among these patients, Graves' disease of only patient 1 was detected by neonatal screening. The mother was not known to have Graves' disease, but after her neonates' diagnosis, she was also diagnosed with Graves' disease. The other patients were closely observed and evaluated periodically after birth and were diagnosed as having NGD.

In patient 2, at gestational age of $27 \mathrm{wk}$, persistent fetal tachycardia was identified, and the mother was referred to our hospital. Maternal thyroid function test revealed maternal Graves' disease and fetal thyrotoxycosis was suspected. Antithyroid drug of propylthiouracil $150 \mathrm{mg} / \mathrm{d}$, via maternal oral administration was initiated. The mother of patient 3 was diagnosed as having Graves' disease at gestational age of 15 wk for the first time and propylthiouracil $(150 \mathrm{mg} / \mathrm{d})$ was started. Mothers of patient 4, 5, 6, 7, and 8 were diagnosed as having Graves' disease before pregnancy and they received propylthiouracil or methimazole.

All eight neonates with Graves' disease were required for methimazole treatment. Of eight neonates, four patients demonstrated normal cord blood or mild low free T4 with low or normal TSH levels (Table 2). Treatment of antithyroid drug was stopped in all these neonates and they need no further intervention of hyperthyroidism. Among eight neonates, we

Table 1. Results of first neonatal screening

\begin{tabular}{cccccc}
\hline Patient & Sex & $\begin{array}{c}\text { TSH } \\
(\mathrm{mU} / \mathrm{L})\end{array}$ & $\begin{array}{c}\text { Free T4 } \\
\text { (ng/dL) }\end{array}$ & $\begin{array}{c}\text { Age (days } \\
\text { after birth) }\end{array}$ & $\begin{array}{c}\text { Final } \\
\text { diagnosis }\end{array}$ \\
\hline 1 & $\mathrm{~F}$ & $<0.5$ & 8.24 & 6 & NGD \\
2 & $\mathrm{M}$ & $<0.5$ & $>12$ & 5 & NGD \\
3 & $\mathrm{~F}$ & $<0.5$ & $>12$ & 5 & NGD \\
4 & $\mathrm{~F}$ & $<0.5$ & 4.12 & 4 & NGD \\
5 & $\mathrm{~F}$ & $<0.5$ & 8.78 & 5 & NGD \\
6 & $\mathrm{~F}$ & $<0.5$ & 9.01 & 5 & NGD \\
7 & $\mathrm{M}$ & $<0.5$ & $>9.8$ & 5 & NGD \\
8 & $\mathrm{M}$ & 12 & 4.13 & 5 & NGD \\
9 & $\mathrm{M}$ & 2.9 & 4.88 & 5 & FDH \\
10 & $\mathrm{M}$ & 1.4 & 4.45 & 5 & RTH \\
11 & $\mathrm{M}$ & 1.7 & 5.72 & 6 & RTH \\
\hline
\end{tabular}

are continuing to follow-up six neonates. They have normal neuropsychological development.

During this screening period, central hypothyroidism due to maternal Graves' disease was not observed.

A case of $\boldsymbol{F D H}$. The first screening of case 9 with FDH showed mildly elevated free T4 $(4.88 \mathrm{ng} / \mathrm{dL})$ and normal TSH levels. As mildly elevated free T4 (4.02 ng/dL) at $23 \mathrm{~d}$ of age were observed in the second screening test, he was referred to our hospital at $45 \mathrm{~d}$ of age. At the referral, he grew well and did not show any sign of hyperthyroidism. Thyroid function of case 9 and his family was summarized in Table 3 . He revealed the extremely high total T4 and T3 levels (Table 3). Serum free $\mathrm{T} 4$ and free $\mathrm{T} 3$ were also high using $\mathrm{T} 4$ and $\mathrm{T} 3$ analog RIA kit (Table 3). By using one labeled antibody radioassay kit, serum free T4 was normal $(1.0 \mathrm{ng} / \mathrm{dL})$ but free T3 was elevated $(82.3 \mathrm{pg} / \mathrm{mL})$ (Table 3). It is known that the measurements of the free $\mathrm{T} 3$ and free $\mathrm{T} 4$ concentrations in serum may give spurious results in FDH, especially in assay using iodothyronine analogs that bind to the abnormal albumin $(16,17)$. His thyroid binding globulin (TBG) level was within the normal range. On the basis of these findings, he was suspected to have FDH. From the interview, his father had been treated with antithyoid drug, but he had no symptom and stopped medication. His father and his elder brother also showed similar results to the infants. Because R216P of the albumin gene has been identified in a Japanese FDH family (14), we investigated this mutation. The result of the albumin gene analysis was shown in Figure 1. The infant, his father, and the elder brother had the mutant and normal bands. On the other hand, the mother had only normal band. Therefore, we confirmed the diagnosis of FDH in this family.

Cases of RTH. Thyroid function tests of two infants (case 10 and 11) with RTH were summarized in Table 4. In these two patients, there was no family history of thyroid disease. Serial thyroid function testing up to $3 \mathrm{y}$ old in both infants continued to show elevated serum free T4 and free T3 with nonsuppressed TSH concentrations. They have not shown any abnormal findings except tachycardia (heart rate, 120-140 beats per minute at rest) so far. We analyzed the TR $\beta$ gene from two patients. Case 10 was heterozygous for transition of $1114 \mathrm{C}>\mathrm{T}$ in exon 8. This results in the substitution of threonine (ACA) by isoleucine (ATA) at position 277 (T277I) (Fig. 2A). Thirty normal Japanese individuals did not harbor this base change of the TR $\beta$ gene. In Case 11, a heterozygous single-base insertion (C) in codon 446-447, which resulted in a frameshift (c.1627_1628insC) was found in exon 9 (Fig. $2 B$ ). This mutation was previously reported (15). Thus, the diagnosis of RTH of two individuals was confirmed.

\section{DISCUSSION}

Our newborn screening program of free $\mathrm{T} 4$ measurement identified 11 infants with persistent elevated free T4 levels during 2000 to 2006. Our main purpose of detection of infants with elevated free T4 by neonatal screening is early diagnosis and medical intervention of some kinds of hyperthyroidism. These conditions include NGD, hyperthyroidism of McCuneAlbright syndrome, and activating TSH receptor mutations. 
Table 2. Serum thyroid test results in eight infants with neonatal Graves' disease

\begin{tabular}{|c|c|c|c|c|c|c|c|c|c|c|c|}
\hline \multirow[b]{2}{*}{ Patient } & \multirow[b]{2}{*}{ Sex } & \multirow[b]{2}{*}{$\begin{array}{c}\text { Gestational } \\
\text { week }\end{array}$} & \multirow[b]{2}{*}{$\begin{array}{c}\text { Birth } \\
\text { weight }\end{array}$} & \multicolumn{2}{|c|}{ Free T4 (ng/dL) } & \multicolumn{2}{|c|}{ Free T3 (pg/mL) } & \multicolumn{2}{|c|}{ TSH (mU/L) } & \multicolumn{2}{|c|}{ TSI* $(\%)$} \\
\hline & & & & $\begin{array}{l}\text { Cord } \\
\text { blood } \dagger\end{array}$ & $\begin{array}{l}\text { Serum (days } \\
\text { after birth) } \neq\end{array}$ & $\begin{array}{c}\text { Cord } \\
\text { blood } \dagger\end{array}$ & $\begin{array}{l}\text { Serum (days } \\
\text { after birth) } \ddagger\end{array}$ & $\begin{array}{c}\text { Cord } \\
\text { blood } \dagger\end{array}$ & $\begin{array}{l}\text { Serum (days } \\
\text { after birth) } \ddagger\end{array}$ & $\begin{array}{c}\text { Cord } \\
\text { blood }\end{array}$ & $\begin{array}{c}\text { Serum (days } \\
\text { after birth) }\end{array}$ \\
\hline 1 & $\mathrm{~F}$ & 36 & 2252 & $\mathrm{ND} \|$ & $6.9(14)$ & $\mathrm{ND} \|$ & $13.4(14)$ & $\mathrm{ND} \|$ & $0.46(14)$ & $\mathrm{ND} \|$ & $450(14)$ \\
\hline $2 \S$ & $\mathrm{F}$ & 32 & 1840 & 1.82 & $>15.0(3)$ & 2.46 & $>20.0(3)$ & $<0.05$ & $<0.05(3)$ & 1313 & $\mathrm{ND} \|$ \\
\hline $3 \S$ & $\mathrm{F}$ & 33 & 1918 & $\mathrm{ND} \|$ & $9.5(2)$ & $\mathrm{ND} \|$ & $>20.0(2)$ & ND\| & $<0.05$ (2) & 1222 & $\mathrm{ND} \|$ \\
\hline $4 \S$ & $\mathrm{F}$ & 35 & 2730 & $\mathrm{ND} \|$ & $5.3(5)$ & $\mathrm{ND} \|$ & $17.8(5)$ & $\mathrm{ND} \|$ & $0.06(5)$ & $\mathrm{ND} \|$ & $\mathrm{ND} \|$ \\
\hline $5 \S$ & M & 37 & 2308 & $\mathrm{ND} \|$ & $4.6(14)$ & $\mathrm{ND} \|$ & $10.4(14)$ & $\mathrm{ND} \|$ & $0.07(14)$ & $\mathrm{ND} \|$ & $\mathrm{ND} \|$ \\
\hline $6 \S$ & $\mathrm{F}$ & 38 & 3656 & 1.47 & $17.4(12)$ & 1.53 & $>20.0(12)$ & 3.19 & $<0.05(12)$ & 325 & $\mathrm{ND} \|$ \\
\hline $7 \S$ & M & 38 & 3520 & 1.96 & $>12.0(5)$ & 1.05 & $>20.0(5)$ & $<0.05$ & $<0.05(5)$ & $\mathrm{ND} \|$ & $530(5)$ \\
\hline $8 \S$ & M & 37 & 2520 & 0.96 & $>12.0(14)$ & 1.60 & $>16.3(14)$ & 7.88 & $<0.05$ (14) & 245 & $418(14)$ \\
\hline
\end{tabular}

* TSI, thyroid stimulating immunoglobulin, normal range $<180 \%$.

$\dagger$ Normal range of cord blood: TSH (mU/L), 3.0-30.6; Free T4 (ng/dL), 1.0-1.7; Free T3 (pg/mL), 1.3-2.4.

\$ Normal range of serum levels after birth. Normal range of 2-3 d: TSH (mU/L), 0.8-12.9; Free T4, (ng/dL) 1.7-4.6; Free T3 (pg/mL), 3.4-8.5. Normal range

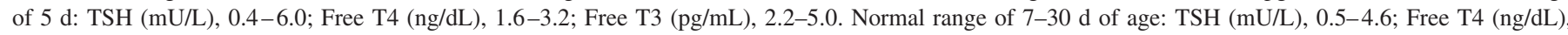
$1.8-2.9 ;$ Free T3 (pg/mL), 2.7-4.6.

$\S$ Except patient 1, mothers were diagnosed as having Graves' disease and receiving antithyroid drug therapy until and after birth. Mothers of patient 2, 3, 4, and 6 were referred to specific centers in our city for maternal or fetal management of Garves' disease from other district.

$\| \mathrm{ND}$, not determined.

Table 3. Serum thyroid test results in a family of FDH

\begin{tabular}{|c|c|c|c|c|c|c|c|c|}
\hline & \multirow[b]{2}{*}{$\begin{array}{c}\text { Total T4 } \\
(\mu \mathrm{g} / \mathrm{dL})\end{array}$} & \multirow[b]{2}{*}{$\begin{array}{c}\text { Total T3 } \\
\text { (ng/dL) }\end{array}$} & \multicolumn{2}{|c|}{ Free T4 (ng/dL) } & \multicolumn{2}{|c|}{ Free T3 $(\mathrm{pg} / \mathrm{mL})$} & \multirow[b]{2}{*}{$\begin{array}{c}\text { TSH } \\
(\mathrm{mU} / \mathrm{L})\end{array}$} & \multirow[b]{2}{*}{$\begin{array}{c}\text { TBG } \\
(\mu \mathrm{g} / \mathrm{mL})\end{array}$} \\
\hline & & & $\begin{array}{l}\text { One-step labeled } \\
\text { antibody radioassay }\end{array}$ & T4 analog RIA & $\begin{array}{l}\text { One-step labeled } \\
\text { antibody radioassay }\end{array}$ & T3 analog RIA & & \\
\hline Patient* & $30<$ & 387 & 1.0 & 37.5 & 82.5 & 18.5 & 2.6 & 19 \\
\hline Father & $30<$ & 502 & 1.2 & 50.9 & 51.4 & 24.3 & 0.82 & 18 \\
\hline Mother & 11.2 & 198 & 1.1 & 1.6 & 3.2 & 3.6 & 1.7 & 22 \\
\hline Brother & $30<$ & 620 & 1.1 & 35.3 & 78.3 & 14.3 & 3.1 & 21 \\
\hline
\end{tabular}

* Normal range at this age: TSH (mU/L), 0.34-3.5; T4 ( $\mu \mathrm{g} / \mathrm{dL}), 9.71-13.45 ; \mathrm{T} 3$ (ng/dL), 142-204; Free T4 (ng/dL), 1.40-2.64; Free T3 (pg/mL), 3.29-4.90. Normal range of adult: TSH (mU/L), 0.55-3.55; T4 ( $\mu \mathrm{g} / \mathrm{dL}), 5.09-12.7$; T3 (ng/dL), 95.7-192; Free T4 (ng/dL), 0.80-1.54; Free T3 (pg/mL), 2.73-3.98; TBG (thyroid binding globulin) $(\mu \mathrm{g} / \mathrm{mL}), 14.5-28.0$.

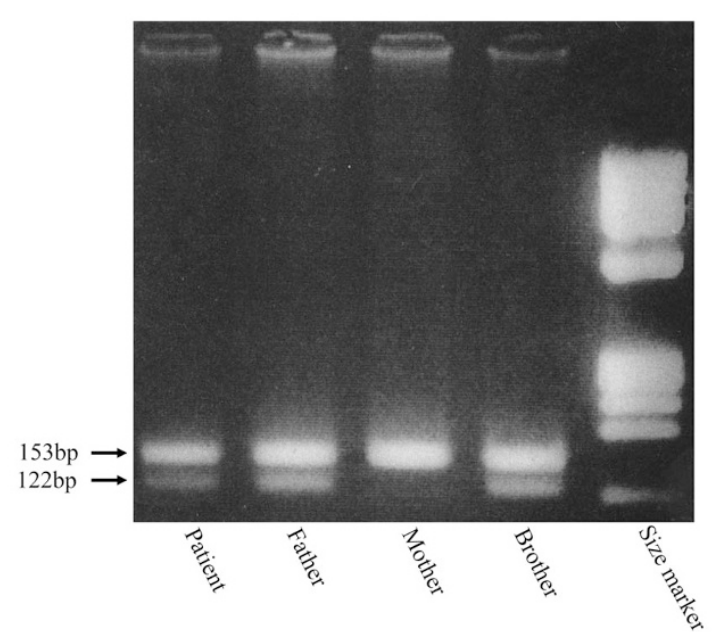

Figure 1. The result of the albumin gene analysis. This figure demonstrated agarose gel electrophoresis of case 9 and his family with FDH. The patient, the father, and the elder brother had both mutant (122 bp) and normal bands (153 bp), indicating that they were heterozygous for R218P mutation. On the other hand, the mother had only the normal band.

The latter two diseases were not found in our screening system, consistent with rarity of two diseases. Instead, our study detected eight neonates with Graves' disease. The first systematic neonatal screening for hyperthyroxinemic disease did not detect any case of NGD among 80,884 infants (12). Different from early screening program in the United States
(1-3 d of age), we collected blood specimen at $4-6 \mathrm{~d}$ of age. Early screening program may have missed some neonates born to mothers on higher doses of antithyroid drugs, because these neonates might have transient hypothyroidism. As far as we know, there were no such babies with NGD not detected by our screening during this period.

Concerning NGD, its occurrence has been estimated one in 10,000 to 50,000 (7-9). By contrast, the estimated occurrence of NGD of our study was 1 in 10,404. For Japanese population, accurate incidence of Graves' disease during pregnancy is not available; however, the prevalence is reported to be similar among whites and Asians (18). Therefore, our study may overestimate the prevalence of NGD. One reason for this is presumably high rate of maternal referral to center hospitals for maternal care in our city. As our city has several specific centers for maternal and neonatal intensive care, severe patients with maternal Graves' disease may have been referred from other regions. Indeed, among eight neonates with NGD, four mothers were referred to center hospitals in our city for management of maternal and fetal Graves' disease.

LaFranchi et al. (12) revealed that FDH could be detected by T4 neonatal screening for the first time. Our study was the second to report that FDH could be also detected by neonatal free T4 screening. Patients with FDH usually show normal free T4 levels, but free T4 levels of FDH can be artificially increased when they are measured by standard immunoassay methods $(14,16,17)$. FDH was estimated to occur in approxi- 
Table 4. Serum thyroid test results of patients with RTH and their parents

\begin{tabular}{|c|c|c|c|c|c|c|}
\hline & Case 10 & Mother & Father & Case 11 & Mother & Father \\
\hline Genotype & T277I & -* & -* & c.1627_1628insC & -* & ND \\
\hline Age at examination & $30 \mathrm{~d} \dagger$ & $29 y$ & $25 \mathrm{y}$ & $32 \mathrm{~d} \dagger$ & $26 y$ & $28 \mathrm{y}$ \\
\hline $\mathrm{TSH}(\mathrm{mU} / \mathrm{L})$ & 3.21 & 0.78 & 1.00 & 11.34 & 1.15 & ND \\
\hline $\mathrm{T} 4(\mu \mathrm{g} / \mathrm{dL})$ & ND & 7.80 & 8.31 & 23.6 & ND & ND \\
\hline Free T4 (ng/dL) & 3.68 & 1.13 & 1,61 & 4.77 & 2.91 & ND \\
\hline $\mathrm{T} 3(\mathrm{ng} / \mathrm{dL})$ & ND & 139 & 108 & 354 & ND & ND \\
\hline Free T3 $(\mathrm{pg} / \mathrm{mL})$ & 8.03 & 2.88 & 3.95 & 13.95 & 2.95 & ND \\
\hline
\end{tabular}

$\mathrm{ND}$, not determined.

* The mutation of the TR $\beta$ gene was not identified.

$\dagger$ Normal range at this age: TSH (mU/L), 0.34-3.5; T4 ( $\mu \mathrm{g} / \mathrm{dL}), 9.71-13.45 ; \mathrm{T} 3$ (ng/dL), 142-204; Free T4 (ng/dL), 1.40-2.64; Free T3 (pg/mL), 3.29-4.90. Normal range of adult: TSH (mU/L), 0.55-3.55; T4 ( $\mu \mathrm{g} / \mathrm{dL}), 5.09-12.7$; T3 (ng/dL), 95.7-192; Free T4 (ng/dL), 0.80-1.54; Free T3 (pg/mL), 2.73-3.98; TBG (thyroid binding globulin) $(\mu \mathrm{g} / \mathrm{mL}), 14.5-28.0$.

A
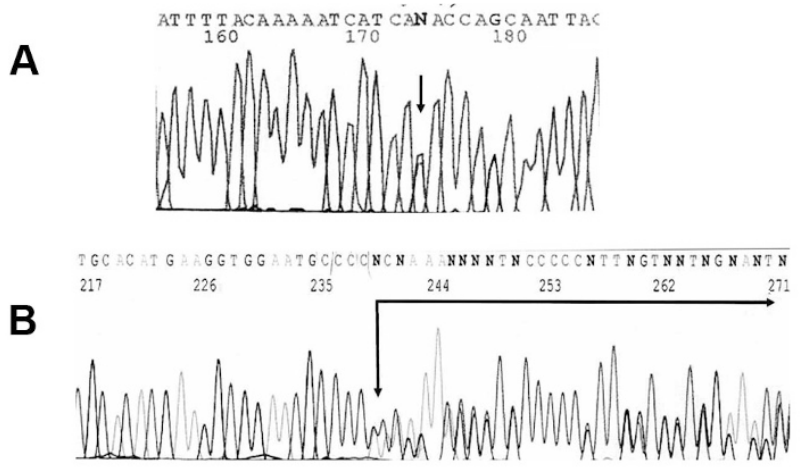

Figure 2. Mutations in the TR $\beta$ gene. (A) Case 10 was heterozygous for transition of $1114 \mathrm{C}>\mathrm{T}$ in exon 8 . This changes threonine (ACA) to isoleucine (ATA) at position 277 (T277I). The mutation site was indicated by an arrow. (B) Sequence chromatograph in case 11. An arrow indicated the mutation site of one base insertion $(C)$ (c.1627_1628insC) in exon 9. Note that after the insertion site, double bands were present (underline).

mately one in 83,000 individuals in our study. The prevalence of FDH is considered to be one in 7000 to one in 16, 000 neonates in Caucasian. Our lower frequency may be due to the ethnic background of the population $(19,20)$. Alternatively, it is plausible that free $\mathrm{T} 4$ screening may miss some individuals with FDH, because free T4 levels of FDH are sometimes within normal range. We prefer the latter speculation.

Regarding RTH, two mutations of the TR $\beta$ gene were identified. Of two mutations, case 10 had a novel mutation of T277I. We did not perform the functional study of this mutant $\mathrm{TR} \beta$. However, this base change was not found in 60 alleles from normal Japanese individuals. Furthermore, previously, a substitution of threonine 277 to alanine was reported in a patient with RTH (21). According to the literature, T277A mutant impaired transactivation function in vitro. Based on these findings, our mutant of T277I is not likely to be merely polymorphism.

It has been reported that RTH could be identified by neonatal screening $(12,22,23)$. Weiss et al. (22) reported the detection of elevated blood T4 level with nonsuppressed TSH level on a newborn screening system, whose mother was diagnosed as having RTH. In addition, routine neonatal cord blood screening for congenital hypothyroidism could detect one infant with RTH (23). Previous systematic screening for hyperthyroxinemic diseases demonstrated that two patients with RTH were identified (12). The authors estimated the frequency of RTH is approximately one in 40, 000. Our study identified two patients with RTH and thus the occurrence was estimated to one in 41,618 , consistent with the results of a previous report.

In summary, follow-up of newborns with persistent elevated free T4 concentrations enables us to detect FDH and RTH. This may be helpful to avoid mistakenly considering patients to have a hyperthyroid state. In addition, early intervention is possible for RTH. Concerning NGD, if pregnant women and fetus with Graves' disease are adequately followed, thyroid status of neonate should be evaluated periodically. Neonatal screening for elevated free T4 is beneficial for identification of NGD, if maternal Graves' disease is unrecognized during pregnancy. Furthermore, as there have been few studies of long-term psychomotor development of NGD after recovery, it is important to follow-up these patients continuously.

\section{REFERENCES}

1. Fisher DA, Dussault JH, Foley TP Jr, Klein AH, LaFranchi S, Larsen PR, Mitchell ML, Murphey WH, Walfish PG 1979 Screening for congenital hypothyroidism: results of screening one million North American infants. J Pediatr 94:700-705

2. Fisher DA 1983 Second International Conference on Neonatal Screening: progress report. J Pediatr 102:653-654

3. Fisher DA 2002 Congenital hypothyroidism. Thyroid Int 3:3-10

4. Hunter MK, Mandel SH, Sesser DE, Miyabira RS, Rien L, Skeels MR, LaFranchi SH 1998 Follow-up of newborns with low thyroxin and nonelevated thyroidstimulating hormone-screening concentrations: results of the 20-year experience in the northwest regional newborn screening program. J Pediatr 132:70-74

5. van Tijn DA, de Vijlder JJ, Verbeeten B Jr, Verkerk PH, Vulsma T 2005 Neonatal detection of congenital hypothyroidism of central origin. J Clin Endocrinol Metab 90:3350-3359

6. Fujiwara F, Fujikura K, Okuhara K, Tsubaki J, Fukushi M, Fujita K, Fujieda K, Tajima T 2008 Central congenital hypothyroidism detected by Neonatal Screening in Sapporo, Japan (2000-2004): it's prevalence and clinical characteristics. Clin Pediatr Endocrinol 17:65-69

7. Zimmerman D 1999 Fetal and neonatal hyperthyroidism. Thyroid 9:727-733

8. LaFranchi SH, Hanna CE 2000 Graves' disease. In: Braverman L, Utiger RD (eds) Wemer and Ingbar's the Thyroid. 8th ed. Lippincott Williams \& Wilkins, Philadelphia, pp 989-997

9. Weetman AP 2000 Graves' disease. N Engl J Med 343:1236-1248

10. Yoshimoto M, Nakayama M, Baba T, Uehara Y, Niikawa N, Ito M, Tsuji Y 1991 A case of neonatal McCune-Albright syndrome with Cushing syndrome and hyperthyroidism. Acta Paediatr Scand 80:984-987

11. Schwab KO, Gerlich M, Broecker M, Söhlemann P, Derwahl M, Lohse MJ 1997 Constitutively active germline mutation of the thyrotropin receptor gene as a cause of congenital hyperthyroidism. J Pediatr 131:899-904

12. LaFranchi SH, Snyder DB, Sesser DE, Skeels MR, Singh N, Brent GA, Nelson JC 2003 Follow up of newborns with elevated screening T4 concentrations. J Pediatr 143:296-301

13. Fisher DA 2003 Neonatal hyperthyroid screening. J Pediatr 143:285-287

14. Wada N, Chiba H, Shimizu C, Kijima H, Kubo M, Koike T 1997 A novel missense mutation in codon 218 of the albumin gene in a distinct phenotype of familial dysalbuminemic hyperthyroxinemia in a Japanese kindred. J Clin Endocrinol Metab $82: 3246-3250$ 
15. Adams M, Matthews C, Collingwood TN, Tone Y, Beck-Peccoz P, Chatterjee KK 1994 Genetic analysis of 29 kindreds with generalized and pituitary resistance to thyroid hormone. J Clin Invest 94:506-515

16. Pohlenz J, Sadow PM, Koffler T, Schönberger W, Weiss RE, Refetoff S 2001 Congenital hypothyroidism in a child with unsuspected familial dysalbuminemic hyperthyroxinemia caused by a mutation $(\mathrm{R} 218 \mathrm{H})$ in the human albumin gene. J Pediatr 139:887-891

17. Pannain S, Feldman M, Eiholzer U, Weiss RE, Scherberg NH, Refetoff S 2000 Familial dysalbuminemic hyperthyroxinemia in a Swiss family caused by a mutant albumin (R218P) shows an apparent discrepancy between serum concentration and affinity for thyroxine. J Clin Endocrinol Metab 85:2786-2792

18. Vanderpump MT, Tunbridge WM 1999 The epidemiology of autoimmune thyroid disease, In: Volpe R (ed) Contemporary Endocrinology, Vol 15: Autoimmune Endocrinopathies. Human Press, Totawas, pp 141-162
19. Arevalo G 1991 Prevalence of familial dysalbuminemic hyperthyroxinemia in serum samples received for thyroid testing. Clin Chem 37:1430-1431

20. Fisher DA 2002 Thyroid disorders. In: Rimoni DL, Connors JM, Pyeritz RE (eds) Principles and Practice of Medical Genetics. 4th ed. Churchill-Livingstone, New York, pp 2183-2202

21. Collingwood TN, Wagner R, Matthews CH, Clifton-Bligh RJ, Gurnell M, Rajanayagam O, Agostini M, Fletterick RJ, Beck-Peccoz P, Reinhardt W, Binder G, Ranke MB, Hermus A, Hesch RD, Lazarus J, Newrick P, Parfitt V, Raggatt P, de Zegher F, Chatterjee VK 1998 A role for helix 3 of the TR-beta ligand-binding domain in coactivator recruitment identified by characterization of a third cluster of mutations in resistance to thyroid hormone. EMBO J 17:4760-4770

22. Weiss RE, Balzano S, Scherberg NH, Refetoff S 1990 Neonatal detection of generalized resistance to thyroid hormone. JAMA 264:2245-2250

23. Wong GW, Shek CC, Lam ST, Tsui MK, Leung SS 1995 Detection of resistance to thyroid hormone by cord blood screening. Acta Paediatr 84:335-336 